\title{
PENATAAN HUBUNGAN KELEMBAGAAN ANTARA PEMERINTAH PROVINSI DENGAN PEMERINTAH KABUPATEN/KOTA
}

\author{
Muh. Hasrul \\ Fakultas Hukum Universitas Hasanudin \\ e-mail: luluhukum@gmail.com
}

\begin{abstract}
ABSTRAK
Penataan hubungan antara Gubernur dengan Bupati/Walikota dalam pelaksanaan tata pemerintahan yang baik dan penataan kelembagaan yang dapat mensinergikan hubungan kewenangan pemerintahan yang efektif antara Pemerintah Provinsi dengan Pemerintah Kabupaten/Kota. Pola hubungan antara Gubernur dengan Bupati/Walikota dalam kaitannya dengan pelaksanaan tata pemerintahan yang baik dalam pelaksanaan peran Gubernur sebagai wakil pemerintah pusat, maka hubungan antara Gubernur dengan Bupati/Walikota bersifat bertingkat di mana Gubernur dapat melakukan peran pembinaan dan pengawasan terhadap penyelenggaraan pemerintahan daerah. Sebaliknya Bupati/Walikota harus senantiasa berkoordinasi dalam penyelenggaraan pemerintahan di daerah, termasuk dalam hubungan antar kabupaten/ kota dengan provinsi.
\end{abstract}

Kata Kunci: hubungan, pemerintah, provinsi, kabupaten/kota.

\begin{abstract}
This Article are trying to find the relationship pattern between the governor and regent/majors, in the field of government management, also to find out managing form that may show a sinergical inter relationship between province and regency government. Based on the research, we found that the relation pattern between governor and regents related to the implementation of good governance in governor enforcement as the representative of the central government is that inter relation between governor and regents/majors are in the gradual level, which governors can do a form of mentoring and supervising. In other hands, regents should always perform coordination in region governance enforcement, including the relationship between regency and province government.
\end{abstract}

Keywords: relationship, government, province, district.

\section{PENDAHULUAN}

Berdasarkan Pasal 18 Undang-Undang Dasar 1945 menegaskan bahwa Negara Kesatuan Republik Indonesia dibagi atas daerah-daerah provinsi dan daerah provinsi dibagi atas kabupaten dan kota yang tiap-tiap provinsi, kabupaten, dan kota itu mempunyai pemerintahan daerah yang diatur dengan undangundang. Negara Republik Indonesia sebagai Negara Kesatuan dalam penyelenggaraan pemerintahannya menganut asas Desentralisasi, Dekonsentrasi, dan Tugas Pembantuan. Pelaksanaan asas Dekonsentrasi diletakkan pada daerah provinsi dalam kedudukannya sebagai Wilayah Administrasi untuk melaksanakan kewenangan pemerintahan tertentu yang dilimpahkan kepada Gubernur sebagai Wakil Pemerintah Pusat di daerah.
Sistem pemerintahan daerah di Indonesia menurut Undang-Undang Dasar 1945 (selanjutnya disingkat UUD 1945) secara jelas mengatur adanya pembagian daerah dengan susunan pemerintahannya yang bersifat otonom yang ditetapkan dengan undangundang. Istilah yang bersifat otonom ini, memberikan keleluasaan kepada daerah untuk mengatur, mengurus serta menyelenggarakan sendiri urusan pemerintahan menurut asas desentralisasi, dekonsentrasi, dan tugas pembantuan atau medebewind. Hal ini ditekankan pada percepatan terwujudnya tingkat kesejahteraan masyarakat melalui peningkatan pelayanan, pemberdayaan dan peran serta dengan memperhatikan prinsip demokrasi, pemerataan, keadilan, keistimewaan dan kekhususan serta potensi 
dan keanekaragaman daerah dalam bingkai Negara Kesatuan Republik Indonesia (selanjutnya disingkat NKRI).

Pemerintah daerah dapat menyelenggarakan urusan pemerintahan yang menjadi wewenangnya, kecuali urusan pemerintahan ditentukan menjadi urusan pemerintah. Dalam menyelenggarakan urusan pemerintahan yang menjadi kewenangan daerah, pemerintahan daerah menjalankan otonomi seluas-luasnya untuk mengatur dan mengurus sendri urusan pemerintahan berdasarkan asas otonomi dan tugas pembantuan. Urusan pemerintahan yang menjadi urusan pemerintah ialah kewenangan dalam bidang politik luar negeri, pertahanan, keamanan, yustisi, moneter dan fiskal, serta agama yang masih merupakan kewenangannya pemerintah pusat. ${ }^{1}$

Konstruksi perwilayahan yang diatur di dalam Undang-Undang Nomor 23 Tahun 2014 tentang Pemerintahan Daerah menempatkan provinsi dan kabupaten/kota sebagai daerah otonom sekaligus sebagai wilayah administrasi. Pengaturan sedemikian ini berarti bahwa antara provinsi dengan kabupaten dan kota mempunyai keterkaitan dan hubungan hirarkis satu sama lain, baik dalam arti status kewilayahan maupun dalam sistem dan prosedur penyelenggaraan pemerintahan.

Adanya pemikiran bahwa provinsi dengan kabupaten/kota terlepas satu sama lain mengingkari prinsip-prinsip NKRI dan UUD 1945, yang secara jelas telah mengatur secara sistematik antara masingmasing tingkat pemerintahan. Menyadari hal itu, maka dalam rangka prinsip-prinsip NKRI, Gubernur sebagai wakil pemerintah menerima pelimpahan wewenang di bidang pemerintahan umum dan pelimpahan wewenang urusan teknis departemen.

Provinsi mempunyai kedudukan sebagai daerah otonom sekaligus adalah wilayah administrasi yaitu wilayah kerja Gubernur untuk melaksanakan fungsifungsi kewenangan yang dilimpahkan kepadanya. Gubernur selain pelaksana asas desentralisasi juga melaksanakan asas dekonsentrasi. Besaran dan isi dekonsentrasi harus mempunyai sifat dekat dengan

${ }^{1}$ Pemberian otonomi kepada daerah merupakan penjabaran dari Pasal 18 UUD 1945, yang diimplementasikan ke dalam Undang-Undang Nomor 22 Tahun 1999 tentang Pemerintahan Daerah, yang telah digantikan dengan Undang-Undang Nomor 32 Tahun 2004 tentang Pemerintahan Daerah. Nilai dasar yang terkandung dalam Undang-Undang Nomor 32 Tahun 2004, Pasal 10 mengenai Pembagian Urusan Pemerintahan kepentingan masyarakat dan bermakna sebagai upaya mempertahankan dan memperkuat persatuan dan kesatuan bangsa serta keutuhan wilayah NKRI dan meningkatkan pemberdayaan, menumbuhkan prakarsa, dan kreatifitas masyarakat serta kesadaran nasional. Oleh sebab itu Gubernur memegang peranan penting sebagai unsur perekat NKRI.

Dalam rangka pelaksanaan prinsip otonomi luas, nyata, dan bertanggungjawab, Pembagian Urusan Pemerintahan antar Pemerintah, Pemerintah Daerah Provinsi, dan Pemerintah Daerah Kabupaten/Kota mengalami perubahan pola sistem pemerintahan di Indonesia dari sentralistik menjadi pola desentralisasi diharapkan dapat memberikan banyak manfaat kepada kemajuan daerah yaitu diberikannya keleluasaan dan kemandirian kepada daerah untuk mengatur dan mengelola urusan rumah tangganya sesuai dengan kewenangannya, di samping kewajibannya untuk menghormati hak-hak dan asal-usul daerah serta nilai-nilai budaya daerah sesuai amanat konstitusi.

Kebijakan desentralisasi tersebut dilaksanakan dengan prinsip otonomi yang luas, nyata dan bertanggungjawab kepada daerah dengan menumbuhkembangkan kualitas demokrasi di daerah, meningkatkan peran serta masyarakat, pemerataan dan keadilan dengan memperhatikan potensi dan keanekaragaman daerah. Prinsip otonomi luas ini yaitu pemberian kewenangan kepada daerah untuk mengurus dan mengatur semua urusan pemerintahan di luar yang menjadi urusan pemerintah yang ditetapkan undang-undang. Kewenangan yang dimiliki oleh daerah ini yakni membentuk, menjalankan serta melaksanakan kebijakan daerah dalam rangka memberikan pelayanan, peningkatan peran serta, prakarsa, dan pemberdayaan masyarakat yang bertujuan pada peningkatan kesejahteraan rakyat.

Dalam UUD 1945 Setelah Amandemen, UndangUndang Nomor 22 Tahun 1999 tentang Otonomi Daerah jo. Undang-Undang Nomor 32 Tahun 2004 tentang Pemerintahan Daerah, kedudukan provinsi tidak ditetapkan secara jelas, padahal keberadaannya sangat dibutuhkan oleh pemerintah nasional untuk menjalankan fungsi koordinasi dan pengawasan terhadap pelaksanaan fungsi pemerintahan dan pelayanan umum oleh Pemerintah Daerah. Dalam Undang-Undang Nomor 23 Tahun 2014 disebutkan bahwa daerah provinsi selain berstatus sebagai 
daerah juga merupakan wilayah administratif yang menjadi wilayah kerja bagi Gubernur sebagai wakil pemerintah pusat dan wilayah kerja bagi Gubernur dalam menyelenggarakan urusan pemerintahan umum di wilayah daerah provinsi.

Provinsi dalam sistem pemerintahan daerah yang berlaku tidak memiliki kewenangan yang jelas atas kabupaten/kota, sebaliknya pemerintah kabupaten/ kota dapat berhubungan langsung dengan Pemerintah Pusat. Akibatnya adalah Daerah Otonom merasa tidak perlu bertanggungjawab kepada provinsi dan kenyataan ini melemahkan fungsi koordinasi dan pengawasan Gubernur.

Selanjutnya pada beberapa daerah muncul permasalahan dalam kerangka hubungan antara Bupati dan Walikota dengan Gubernur. Di satu sisi Bupati dan Walikota menganggap tidak perlu melakukan koordinasi dengan Gubernur karena tidak adanya hubungan hirarki di antara mereka. Sedangkan di pihak Gubernur merasa bahwa UndangUndang Nomor 32 Tahun 2004 tentang Pemerintahan Daerah mengurangi kekuasaan mereka terhadap Daerah. Timbulnya permasalahan dan ketegangan hubungan antara Gubernur dengan Bupati dan Walikota pada beberapa daerah lebih disebabkan oleh adanya perbedaan persepsi terhadap kedudukan dan hubungan di antaranya sebagaimana diatur oleh Undang-Undang Nomor 32 Tahun 2004 tentang Pemerintahan Daerah.

\section{PERUMUSAN MASALAH}

Mendasarkan pada latar belakang, maka penelitian dalam penulisan ini mengkaji tentang pola hubungan kelembagaan antara pemerintah provinsi dengan kabupaten/kota dalam kaitannya dengan pelaksanaan tata pemerintahan yang baik.

\section{METODE PENELITIAN}

Dalam penulisan ini menggunakan tipe penelitian normatif dengan pendekatan masalah statute approach dan conceptual approach. Adapun undang-undang yang dikaji adalah: Undang-Undang Dasar 1945, Undang-Undang Nomor 22 Tahun 1999 tentang Otonomi Daerah, Undang-Undang Nomor 28 Tahun 1999 tentang Penyelenggara Negara Yang Bersih dan Bebas Dari Kolusi, Korupsi, dan Nepotisme, dan Undang-Undang Nomor 32 Tahun 2004 tentang Pemerintahan Daerah, serta Peraturan
Pemerintah Nomor 23 Tahun 2011 tentang Perubahan atas Peraturan Pemerintah Nomor 19 Tahun 2010 tentang Tatacara Pelaksanaan Tugas dan Wewenang Serta Kedudukan Keuangan Gubernur Sebagai Wakil Pemerintah di Wilayah Provinsi. Sedangkan konsep yang digunakan adalah Konsep Negara Hukum, Konsep Otonomi Daerah, dan Konsep Kewenangan.

\section{PEMBAHASAN}

\section{Konsep Negara Hukum}

Dalam kepustakaan Indonesia, istilah negara hukum merupakan terjemahan langsung dari rechtsstaat. Disamping itu dalam wacana akademik digunakan pula istilah rule of law yang juga dimaksudkan sebagai negara hukum. Meskipun ketiga istilah tersebut (negara hukum, rechsstaat, dan rule of law) terdapat pandangan yang menyamakan dan membedakannya namun yang pasti ketiga konsep tersebut mengusung tujuan yang sama yaitu untuk mencegah terjadinya penyalahgunaan kekuasaan oleh penguasa secara sewenang-wenang agar hak asasi manusia (yang selanjutnya disebut dengan HAM) tetap terjamin dan terlindungi.

Sejarah perkembangan cita negara hukum berawal dari konsep pemikiran Plato (427-347 SM) yang kemudian dilanjutkan oleh Aristoteles (384-322 SM). Plato dalam bukunya yang berjudul Politea memberikan respons terhadap kondisi negara yang memprihatinkan karena saat itu dipimpin oleh orangorang atas dasar kesewenang-wenangan. Ide Plato dikembangkan lebih lanjut oleh Aristoteles. Dalam pandangannya, suatu negara yang baik ialah negara yang diperintah dengan konstitusi dan berkedaulatan hukum. Pandangan ini termuat dalam karyanya yang berjudul Politica. Ia juga mengemukakan bahwa terdapat tiga unsur dari pemerintahan berkonstitusi, yaitu: pertama, pemerintahan dilaksanakan untuk kepentingan umum, kedua, pemerintah dilaksanakan menurut hukum yang berdasar ketentuan-ketentuan umum, bukan hukum yang dibuat secara sewenangwenang yang mengesampingkan konvensi dan konstitusi, ketiga, pemerintah berkonstitusi, berarti pemerintah yang dilaksanakan atas kehendak rakyat, bukan berupa paksaan-tekanan seperti yang dilaksanakan pemerintahan despotis.

Ide mengenai negara hukum ini dalam catatan sejarahnya pernah ditinggalkan orang dan menghilang. Kemudian muncul kembali di "barat" 
pada awal abad XVII. Kemunculan ulang pemikiran tentang negara hukum ini dilatari oleh situasi dan kondisi yang sama ketika era Plato dan Aristoteles mengemukakan idenya tentang negara hukum, yaitu merupakan reaksi terhadap kekuasaan yang absolute dan sewenang-wenang. ${ }^{2}$

Menurut Frederich Julius Stahl, ${ }^{3}$ ciri dari negara hukum Eropa continental atau rechtsstaat meliputi: mengakui dan melindungi hak asasi manusia; untuk melindungi hak asasi tersebut penyelenggara negara harus berdasarkan pada teori trias politica; dalam menjalankan tugasnya, pemerintah berdasar atas undang-undang atau wetmatig bestuur; apabila dalam menjalankan tugasnya berdasarkan undangundang pemerintah masih melanggar hak asasi (campur tangan pemerintah dalam kehidupan pribadi seseorang), maka ada pengadilan administrasi yang akan menyelesaikannya.

Selanjutnya teori negara hukum menurut Rosenthal ${ }^{4}$ menegaskan bahwa: ada desentralisasi keuangan, ada perimbangan dalam politik, ada keterbukaan pemerintahan dan pertimbangan yang cermat tentang kepentingan rakyat dalam setiap keputusan pemerintah.

Sementara itu menurut Albert Venn Dicey ciri dari negara hukum atau rule of law meliputi: supremacy of law, dalam arti tidak boleh ada kesewenang-wenangan, sehingga seseorang hanya boleh dihukum jika melanggar hukum; equality before the law, artinya kedudukan yang sama di depan hukum; human rights, yakni terjaminnya hak asasi manusia oleh undang-undang dan keputusankeputusan pengadilan.

Konsep Negara Hukum juga dikemukakan oleh Berman, ${ }^{5}$ The Rule Under Law yaitu mengadakan pengaturan di bawah kewenangan hukum atau mengadakan perubahan sebagaimana di atur hukum;

${ }^{2}$ Pemikiran-pemikiran yang muncul pada abad XVII ini, merupakan embrio konsep negara hukum yang makin berkembang di abad XIX dan mengilhami pemikiran John Locke (1632-1704), Charles de Secondat Baron de La Brede et de Montesquieu (1689-1755), dan Jean Jacques Rousseau (1712-1778).

${ }^{3}$ Ridwan H.R., Hukum Administrasi Negara, UII Press, Yogyakarta, 2002, h. 2. Lihat pula dalam Ni'matul Huda, 2007, Pengawasan Pusat Terhadap Daerah Dalam Penyelenggaraan Pemerintahan Daerah, FH UII Press, Yogyakarta, h. 57.

${ }^{4}$ M.A.P. Bovens, et.all., Rechts Staaten Sturing, W.E.J. Tjeenk Willing, Zwolle, 1987, h. 54.

${ }^{5}$ Ibid., h. 6
Rule of Law yang mencakup separation power, checks and balances dan equality before the law.

Utrecht ${ }^{6}$ kemudian mengingatkan bahwa agar Negara Hukum dapat terwujud sesuai tujuannya, maka pada Negara Hukum itu harus didasarkan pada: Pertama, Asas Legliteit, yaitu semua tindakan alat-alat negara harus didasarkan atas hukum dan dibatasi oleh peraturan perundang-undangan yang mempunyai kekuasaan tertinggi dalam negara, yaitu Undang-Undang Dasar yang terdiri atas peraturanperaturan hukum dan asas-asas hukum. Kedua, Asas perlindungan kebebasan dan hak pokok manusia/ semua orang yang ada dalam wilayah negara.

Internasional Commission of Jurists dalam konferensinya di Bangkok Tahun 1965 telah memperluas konsep mengenai Rule of Law, Rule of Law in The Modern Age. Disamping hak-hak politik, hak-hak sosial dan ekonomi harus diakui dan dipelihara, dalam arti bahwa harus dibentuk standarstandar dasar sosial dan ekonomi.

Hirch Ballin ${ }^{7}$ mengemukakan pandangannya tentang ciri-ciri negara hukum, sebagai berikut: Penguasa harus terikat pada hukum, Negara harus menghormati hak-hak mengenyam kebebasan, Setiap kebijakan pemerintah harus berdasarkan undangundang, Mengupayakan terwujudnya keadilan sosial; dan Hukum harus jelas dan stabil.

Jimly Asshiddiqie ${ }^{8}$ mengemukakan bahwa ada sebelas prinsip pokok negara hukum atau rechtsstaat yang belaku di zaman sekarang. Kesebelas prinsip pokok tersebut merupakan pilar-pilar utama yang menyangga bediri tegaknya negara hukum modern yang meliputi: supremasi hukum atau Supremacy of Law; persamaan dalam hukum atau Equality Before the Law; azas legalitas atau Due Process of Law; pembatasan kekuasaan; organ-organ eksekutif independen; peradilan bebas dan tidak memihak; peradilan tata usaha negara; peradilan tata negara; perlindungan HAM; bersifat demokratis atau Democratische Rechtsstaat; dan berfungsi sebagai sarana mewujudkan tujuan bernegara atau Welfare Rechtsstaat.

${ }^{6}$ E. Utrech, Pengantar Hukum Administrasi Negara Indonesia, Ichtiar Baru, Jakarta, 1990, h. 132.

${ }^{7}$ Hamzah Halim, H.S. Muh. Ikhsan Saleh, Persekongkolan Rezim Politik Lokal, Study atas Relasi Antara Eksekutif dan Legislatif, Pukap Indonesia, Makassar, 2009, h. 22.

${ }^{8}$ Ibid., h. 23. 
Marbun dan Mahfud ${ }^{9}$ mengklasifikasikan negara hukum dalam dua bentuk, yaitu: pertama, Legal State (Negara Hukum yang Statis), yaitu negara yang bertindak sebagai wasit, penjaga malam atau menjamin keamanan yang dapat bertindak apabila terdapat gangguan keamanan; dan kedua, Welfare State (Negara Hukum Kesejahteraan/Dinamis) yaitu negara hukum yang tidak semata-mata menjadi penjaga malam tetapi juga menjadi penjamin kesejahteraan warga masyarakat.

Penegasan Indonesia sebagai negara hukum yang selama ini diatur di dalam penjelasan UUD 1945, dalam perubahan ketiga UUD Tahun 1945 Pasal 1 ayat (3), yang menegaskan bahwa Negara Indonesia adalah Negara Hukum. Konsekuensi ketentuan ini adalah bahwa setiap sikap, kebijakan, dan perilaku alat negara dan penduduk harus berdasar dan sesuai dengan hukum. Sekaligus ketentuan ini mencegah terjadinya kesewenang-wenangan dan arogansi kekuasaan, baik yang diakukan oleh alat negara maupun penduduk. Perbedaan yang paling asasi dari Negara hukum Indonesia hanya terletak pada dasar bertumpu yaitu keseimbangan hubungan antara pemerintah dan rakyat.

\section{Konsep Otonomi Daerah}

Pemahaman tentang istilah otonomi secara etimologi berasal dari bahasa/kata latin autos yang bermakna sendiri, dan nomos yang berarti aturan. Berdasarkan etimologi tersebut kata otonomi ini berarti zelwetgeving atau pengundangan sendiri atau mengatur/memerintah sendiri. Pemaknaan otonomi menurut Undang-Undang Nomor 22 Tahun 1999 tentang Pemerintahan Daerah yang kemudian telah digantikan dengan Undang-Undang Nomor 32 Tahun 2004 tentang Pemerintahan Daerah terletak pada adanya kewenangan untuk mengatur dan mengurus sendiri urusan pemerintahan dan kepentingan masyarakat yang menurut Van der $\operatorname{Pot}^{10}$ makna dari otonomi yaitu pada aspek pengaturan atau regeling dan pengurusan atau bestuur urusannya sendiri.

Gie berpendapat bahwa otonomi adalah wewenang untuk menyelenggarakan kepentingan

${ }^{9}$ S.F. Marbun dan Moh. Mahfud, Pokok-Pokok Hukum Administrasi Negara, Liberty, Yogyakarta, 2000, h. 43.

10 Lihat dalam Bhenyamin Hoessein, "Kebijakan Desentralisasi”, Jurnal Administrasi Negara, Vol. 1 No. 02 Tahun 2002. sekelompok penduduk yang berdiam dalam suatu lingkungan wilayah tertentu. Wewenang penyelenggaraan yang dimaksudkan Gie dalam otonomi yaitu wewenang untuk mengatur, mengurus, mengendalikan, dan mengembangkan berbagai hal yang dianggap perlu bagi kehidupan para penduduk.

Menurut Manan bahwa makna kemandirian dalam pengertian otonomi daerah adalah kebebasan karena tidak akan ada kemandirian tanpa dibarengi dengan kebebasan untuk mengatur dan mengurus rumah tangganya sendiri. Namun menurut Hatta, makna otonomi lebih pada penekanan aspek demokrasi, karena menurut Hatta bahwa dengan memberikan otonomi kepada daerah tidak saja berarti melaksanakan demokrasi, tetapi juga mendorong berkembangnya auto-aktivitet. Auto-aktivitet artinya bertindak sendiri, melaksanakan sendiri apa yang dianggap penting bagi lingkungan sendiri dan dengan berkembangnya auto-aktivitet, akan tercapailah apa yang dimaksudkan dengan demokrasi yaitu pemerintahan yang dilaksanakan oleh rakyat untuk rakyat. Rakyat tidak saja menentukan nasibnya sendiri, melainkan juga dan terutama memperbaiki nasibnya sendiri.

Hal senada juga tertuang dalam Pasal 1 angka 5 UU Nomor 32 Tahun 2004 bahwa otonomi daerah adalah hak, wewenang dan kewajiban daerah otonom untuk mengatur dan mengurus sendiri urusan pemerintahan dan kepentingan masyarakat setempat sesuai dengan peraturan perundang-udangan. Secara normatif otonomi daerah lebih bermakna hak dan wewenang untuk mengurus kepentingan daerahnya sendiri.

Operasionalisasi otonomi ini mencakup 2 (dua) komponen utama otonomi. Pertama, komponen wewenang menetapkan dan melaksanakan kebijaksanaan sebagai komponen yang mengacu pada konsep pemerintahan yang terdapat dalam pengertian otonomi. Kedua, komponen kemandirian sebagai komponen yang mengacu pada kata oleh, dari dan untuk rakyat. Kemandirian ini mendorong tumbuhnya aktivitas yang sebagaimana dikemukakan Moh. Hatta sebagai prakarsa dan aktivitas sendiri.

Kaloh menegaskan bahwa otonomi adalah kewenangan untuk mengatur dan mengurus rumah tangga daerah yang melekat baik pada lokal kesatuan maupun pada lokal federasi karena kewenangan mengatur dan mengurus rumah tangga daerah berada 
pada pemerintah lokal yang kesatuannya meliputi segenap kewenangan pemerintah kecuali bebarapa urusan tertentu yang masih dipegang oleh pusat. ${ }^{11}$

Dengan diletakkannya mengenai sistem otonomi di dalam UUD 1945, secara yuridis memberikan landasan dan pedoman yang kuat bagi undang-undang organik di bidang pemerintahan daerah di masa datang. Pengaturan yang demikian ternyata telah diakomodir oleh TAP MPR RI No. XV/MPR/1998 dan Undang-Undang No. 22 Tahun 1999 yang diubah dengan Undang-Undang No. 32 Tahun 2004.

\section{Konsep Kewenangan}

Pada Kamus Besar Bahasa Indonesia, kata wewenang disamakan dengan kata kewenangan, yang diartikan sebagai hak dan kekuasaan untuk bertindak, kekuasaan membuat keputusan, memerintah dan melimpahkan tanggung jawab kepada orang/badan lain. ${ }^{12}$ Menurut Bagir Manan, ${ }^{13}$ wewenang dalam bahasa hukum tidak sama dengan kekuasaan. Kekuasaan hanya menggambarkan hak untuk berbuat atau tidak berbuat. Dalam hukum wewenang berarti hak dan kewajiban. Wewenang dalam kaitannya dengan otonomi daerah adalah hak yang memiliki pengertian kekuasaan mengatur sendiri atau zelfregelen dan mengelola sendiri atau zelfbesturen.

Lubis menguraikan pengertian wewenang dengan membedakan tugas atau functie adalah satuan urusan pemerintahan yang dibebankan kepada organ tertentu untuk dilaksanakan, dan wewenang adalah pelaksanaan teknik urusan yang dimaksud. ${ }^{14}$

Dikemukan pula oleh Tonnaer ${ }^{15}$ bahwa kewenangan pemerintahan adalah kemampuan untuk melaksanakan hukum positif, sehingga dengan demikian dapat pemerintah dengan warga negara. Sementara itu, Marbun ${ }^{16}$ memberikan pengertian berbeda antara kewenangan dan wewenang. Menurutnya kewenangan atau authority/gezag adalah kekuasaan yang diformalkan baik terhadap

${ }^{11}$ J. Kaloh, Mencari Bentuk Otonomi Daerah, Rineka Cipta, Jakarta, 2002, h. 3.

${ }^{12}$ Anton Moeliono, dkk., Kamus Besar Bahasa Indonesia, Balai Pustaka, Jakarta, 1989, h. 101.

${ }^{13}$ Ridwan HR., Op.Cit., h. 74.

${ }^{14}$ M. Solly Lubis, Hukum Tata Negara, Mandar Maju, Bandung, 2002, h. 56.

${ }^{15}$ Ridwan HR., Op.Cit., h. 27.

${ }^{16}$ S.F. Marbun, dkk., Dimensi-Dimensi Pemikiran Hukum Administrasi Negara, UII Press, Yogyakarta, 2001, h. 122. segolongan orang tertentu maupun terhadap sesuatu bidang pemerintahan tertentu secara bulat. Sedangkan wewenang atau competence, bevoegdheid hanya mengenai bidang tertentu saja. Dengan demikian, kewenangan berarti kumpulan dari wewenangwewenang atau rechtsbevoegdheden. Menurutnya, wewenang adalah kemampuan untuk melakukan suatu tindakan hukum publik atau kemampuan bertindak yang diberikan peraturan perundangundangan untuk melakukan hubungan hukum.

Secara konseptual, istilah kewenangan tidak bisa disamakan dengan istilah urusan pemerintahan, karena kewenangan dapat diartikan sebagai hak atau kewajiban untuk menjalankan satu atau beberapa fungsi manajemen yaitu pengaturan, perencanaan, pengorganisasian, pengurusan, pengawasan atas suatu objek tertentu yang ditangani oleh pemerintah. Cheema dan Rondinelli menyatakan bahwa kewenangan lebih tepat diartikan dengan authority, sedangkan Hans Antlov menggunakan istilah Power.

Kewenangan merupakan salah satu konsepsi inti dalam Hukum Administrasi Negara. Kewenangan adalah apa yang disebut kekuasaan formal, kekuasaan yang berasal dari kekuasaan legislatif (diberikan oleh undang-undang) atau dari kekuasaan eksekutif administrasi.

Di dalam kewenangan terdapat wewenangwewenang. Wewenang adalah kekuasaan untuk melakukan suatu tindakan hukum publik, misalnya wewenang menandatangani/menerbitkan suratsurat izin dari seorang pejabat atas nama menteri, sedangkan kewenangan tetap berada di tangan menteri. Lahirnya Undang-Undang nomor 32 tahun 2004 tentang Pemerintahan Daerah adalah era baru bagi keberlangsungan pemerintahan di daerah. Terkandung makna distribusi kekuasaan atau distribution of power, daerah diberikan keleluasaan untuk mengatur serta mengurus pemerintahannya sendiri. Humes IV menjelaskan bahwa dasar pendistribusian kewenangan antara pusat dan daerah terdiri atas dua pendekatan yakni: pertama, pendistribusian kewenangan atau distribution of power berdasarkan pada basis kewilayahan atau teritorial; dan kedua, berdasarkan pada basis fungsional. Pada basis teritorial kewenangan untuk menyelenggarakan urusan-urusan lokal yang didistribusikan pada satuan wilayah atau state local government dan pada pemerintahan lokal 
atau self local government. Pada basis fungsional, kewenangan untuk menyelenggarakan urusan-urusan lokal didistribusikan pada kementerian-kementerian pusat yang bersifat khusus dan agen-agennya yang berada di luar kantor pusatnya sebagai pelaksana kebijakannya.

Adanya pemberian dan atau pembagian wewenang dari pemerintah pusat kepada pemerintah daerah baik dalam bentuk atribusi maupun delegasi, dimaksudkan agar pemerintah daerah dapat mengurus sendiri urusan rumah tangganya.Termasuk didalamnya wewenang menetapkan peraturan sendiri di daerah dalam rangka pemyelenggaraan urusan rumah tangga daerah yang dikenal dengan Peraturan Daerah.

\section{Urusan Pemerintah Pusat dan Daerah}

Dalam sistem pemerintahan dan ketatanegaraan Indonesia, pemerintah daerah merupakan subsistem dari pemerintahan negara. Berkenaan dengan hal tersebut, maka terdapat hubungan antar tingkat pemerintahan yang saling mempengaruhi sehingga tercipta satu kesatuan pemerintahan negara. Dengan demikian, dalam suatu pemerintahan negara terdapat dua subsistem yaitu, pertama, Pemerintahan pusat yang terdiri dari Presiden yang dibantu oleh para menterinya; dan kedua, subsistem pemerintahan daerah, yang terdiri dari Kepala Daerah dan DPRD dengan segenap perangkat daerah yang mendukung penyelenggaraan pemerintahan daerah, sampai dengan pemerintah desa.

Urusan yang diserahkan kepada daerah disertai dengan sumber pendanaan, pengalihan sarana dan prasarana, serta kepegawaian sesuai dengan urusan yang didesentralisasikan.Sedangkan urusan pemerintahan yang dilimpahkan kepada Gubernur disertai dengan pendanaan sesuai dengan urusan yang didekonsentrasikan.

Dalam rangka melaksanakan urusan pusat yang ada di daerah dilaksanakan oleh Kepala Pemerintahan Provinsi atau Kepala Daerah Provinsi yang disebut Gubernur sebagai wakil pusat di daerah dan instansi vertikal yang menangani urusan pusat yang tidak diserahkan kepada daerah. Sebagai wakil pusat di daerah dalam konteks Integrated Prefectoral System Gubernur mempunyai kewenangan untuk mengkoordinir, mengawasi, melakukan supervisi dan memfasislitasi agar daerah bawahannya mampu menjalankan otonomi secara optimal. Gubernur juga mempunyai Tutelage Power atau Kekuatan Perwalian/ Pengawasan, yaitu menjalankan kewenangan Pusat untuk membatalkan kebijakan daerah bawahannya yang bertentangan dengan kepentingan umum atau pun peraturan perundangan yang lebih tinggi.

\section{Pola Hubungan Antara Gubernur Dengan Bupati/ Walikota Dalam Kaitannya Dengan Pelaksanaan Tata Pemerintahan Yang Baik}

Pembahasan mengenai pola hubungan antara Gubernur dan Bupati/Walikota dalam rangka mewujudkan tata pemerintahan yang baik atau good governance tidak terlepas pada pembahasan mengenai pola hubungan pusat dengan daerah serta pola hubungan provinsi dengan kabupaten/ kota. Pola hubungan yang dimaksud ini tentunya tidak dapat dilepaskan dalam kerangka teori bentuk negara dan sistem pemerintahan Negara Republik Indonesia. Bentuk Negara Republik Indonesia sebagaimana ditegaskan di dalam Pasal 1 ayat (1) UUD 1945 ialah Negara Kesatuan, yang berbentuk Republik. Perumusan dalam Pasal 1 ayat (1) UUD 1945 dalam mendirikan negara yang kemudian ditegaskan kembali dalam amandemen UUD 1945 dalam ketentuan Pasal 37 ayat (5) yang menyatakan bahwa Khusus mengenai bentuk Negara Kesatuan RI tidak dapat dilakukan perubahan. Sedangkan sistem pemerintahan RI dalam kaitan dengan hubungan pusat dan daerah adalah sebagaimana ditegaskan di dalam Pasal 18, 18A, dan 18B UUD 1945.

Pasal 18, Pasal 18A, dan Pasal 18B UUD 1945 tersebut di atas merupakan dasar utama dalam terbentuknya suatu pemerintahan di daerah. Di samping itu, penerapan Pasal 18 UUD 1945 ini pun merupakan cerminan demokrasi yang terlaksana dalam proses desentralisasi. Melihat pada bentuk Negara Indonesia, yaitu Negara Kesatuan dengan wilayahnya yang luas dan jumlah penduduknya yang banyak, maka tidak memungkinkan pemerintah pusat dapat secara efektif menjalankan fungsi-fungsi pemerintahan tanpa melibatkan perangkat daerah. Oleh karena itu pemerintah pusat menyerahkan beberapa kewenangannya kepada daerah otonom ataupun kepada alat kelengkapan/organ atau kepada instansi vertikal di wilayah tertentu melalui konsep desentralisasi dan dekonsentrasi. Dengan menjalankan desentralisasi dengan pola pemencaran 
kekuasaan secara vertikal ini, maka tercipta suatu hubungan antara pemerintah pusat dengan pemerintah daerah.

Sebagaimana telah dijelaskan di atas bahwa UUD 1945 menyatakan bahwa NKRI dibagi atas daerah provinsi, kabupaten, dan kota. Pemerintahan daerah provinsi, kabupaten, dan kota mengatur dan mengurus sendiri urusan pemerintahan menurut asas otonomi dan tugas pembantuan, kecuali urusan pemerintahan yang oleh undang-undang ditentukan sebagai urusan pemerintah pusat dilaksanakan melalui asas dekonsentrasi dan tugas-tugas pembantuan. Dalam NKRI, pemerintah memiliki peran yang sangat kuat dalam menjaga kepentingan nasional dan pemerintah memiliki kewenangan untuk menjamin bahwa kebijakan nasional dapat dilaksanakan secara efektif di seluruh wilayah Indonesia.

Penyerahan urusan pemerintahan yang sebagian besar diberikan kepada pemerintah kabupaten/kota menuntut pemerintah untuk memastikan bahwa kabupaten/kota mengatur dan mengurus urusan tersebut sesuai dengan norma, standar, prosedur dan kriteria yang ditetapkan oleh pemerintah pusat. Untuk memenuhi kebutuhan tersebut UndangUndang Nomor 32 Tahun 2004 tentang Pemerintahan Daerah, menempatkan posisi Gubernur selaku kepala daerah provinsi sekaligus berkedudukan sebagai wakil pemerintah di wilayah provinsi. Dalam hal ini Gubernur mempunyai fungsi menjembatani dan memperpendek rentang kendali pelaksanaan tugas dan fungsi pemerintah dalam penyelenggaraan pemerintahan di wilayah provinsi.

Dalam Pasal 38 Undang-Undang Nomor 32 Tahun 2004 tentang Pemerintahan Daerah, Gubernur sebagai wakil pemerintah di wilayah provinsi mempunyai tugas dan wewenang: Pembinaan dan pengawasan, koordinasi penyelenggaraan pemerintahan daerah kabupaten/kota, Koordinasi pembinaan dan pengawasan penyelenggaraan tugas pembantuan di daerah provinsi dan kabupaten/kota.

Di samping pelaksanaan tugas tersebut, Gubernur sebagai wakil pemerintah pusat mempunyai tugas: Menjaga kehidupan berbangsa, bernegara dalam rangka memelihara keutuhan NKRI; Menjaga dan mengamalkan ideologi Pancasila dan kehidupan demokrasi; Memelihara stabilitas politik; serta Menjaga etika dan norma penyelenggaraan pemerintahan di daerah.
Idealnya, peran Gubernur sebagai wakil pemerintah pusat untuk melaksanakan pembinaan, pengawasan, koordinasi dan penyelarasan kegiatan pembangunan di daerah akan dapat mengurangi ketegangan yang selama ini sering terjadi pada hubungan antara Bupati/Walikota dan Gubernur. Perbedaan dalam memahami pola hubungan antar kedua tingkatan pemerintahan tersebut cenderung mempersulit koordinasi dan sinergi dalam perencanaan dan pelaksanaan kegiatan di kabupaten/ kota.

Pengaturan peran Gubernur sebagai wakil pemerintah pusat didasarkan pada Peraturan Pemerintah Nomor 19 Tahun 2010 tentang Tatacara Pelaksanaan Tugas dan Wewenang Serta Kedudukan Keuangan Gubernur Sebagai Wakil Pemerintah di Wilayah Provinsi jo. Peraturan Pemerintah Nomor 23 Tahun 2011 tentang Perubahan atas Peraturan Pemerintah Nomor 19 Tahun 2010 tentang Tatacara Pelaksanaan Tugas dan Wewenang Serta Kedudukan Keuangan Gubernur Sebagai Wakil Pemerintah di Wilayah Provinsi. Pendanaan tugas dan wewenang Gubernur sebagai wakil Pemerintah dibebankan pada Anggaran Pendapatan dan Belanja Negara (APBN) melalui mekanisme dana dekonsentrasi yang dituangkan dalam rencana kerja dan anggaran Kementerian Dalam Negeri. Dekonsentrasi Kementerian Dalam Negeri merupakan bagian dari Program Penguatan Penyelenggaraan Pemerintahan Umum dan Kegiatan Penyelenggaraan Hubungan Pusat dan Daerah serta Kerjasama Daerah.

Penguatan fungsi Gubernur sebagai wakil pemerintah pusat di wilayah provinsi juga dimaksudkan memperkuat hubungan antar tingkatan pemerintahan. Dalam pelaksanaan peran Gubernur sebagai wakil pemerintah pusat, maka hubungan antara Gubernur dengan Bupati/Walikota bersifat bertingkat di mana Gubernur dapat melakukan peran pembinaan dan pengawasan terhadap penyelenggaraan pemerintahan daerah. Sebaliknya Bupati/Walikota dapat melaporkan permasalahan yang terjadi dalam penyelenggaraan pemerintahan di daerah, termasuk dalam hubungan antar kabupaten/ kota.

Hubungan antara pusat dan daerah dalam penerapan desentralisasi tidak terlepas pada pembicaraan mengenai konsep dasar otonomi daerah. Sesuai dengan dasar pengertian otonomi 
bahwa suatu daerah otonom diberikan kemandirian/ kebebasan dalam mengatur dan mengurus urusan rumah tangganya sendiri, namun kemandirian atau kebebasan itu tidaklah mutlak karena bahwasannya daerah pun masih membutuhkan campur tangan pemerintah pusat terutama dalam bidang pengawasan, keuangan, dan kewenangan. Selain bidang pengawasan, keuangan, dan kewenangan, dalam Undang-Undang Nomor 32 Tahun 2004 tentang Pemerintahan Daerah disebutkan bidang lain dalam pola hubungan antara pusat dan daerah, yaitu dalam bidang pelayanan umum dan juga bidang pemanfaatan sumber daya alam. Campur tangan pemerintah pusat terhadap daerah otonom merupakan kaitan yang tidak dapat dipisahkan satu sama lain.

Kepemerintahan adalah suatu institusi, mekanisme, proses, dan hubungan yang komplek melalui warga negara atau citizens dan kelompokkelompok yang mengartikulasikan kepentingannya, melaksanakan hak dan kewajibannya dan menengahi atau memfasilitasi perbedaan-perbedaan di antara mereka. Gerald Meier ${ }^{17}$ memberikan pengertian good governance, yaitu Prinsip mengatur pemerintahan yang memungkinkan layanan publiknya efisien, sistem pengadilannya bisa diandalkan, dan administrasinya bertanggungjawab pada publik, dan dimana mekanisme pasar merupakan pertimbangan utama dalam proses pembuatan keputusan mengenai alokasi sumberdaya.

Selanjutnya Sedarmayanti mengelompokkan unsur-unsur kepemerintahan atau governance stakeholders ke dalam 3 (tiga) kategori, yaitu:

Pertama, Negara/Pemerintahan: konsepsi kepemerintahan pada dasarnya adalah kegiatan kenegaraan, tetapi lebih jauh dari itu melibatkan pula sektor swasta dan kelembagaan masyarakat madani atau Civil Society Organization.

Kedua, Sektor Swasta: Pelaku sektor swasta mencakup perusahaan swasta yang aktif dalam interaksi dalam sistem pasar, seperti: industri pengolahan atau manufacturing, perdagangan, perbankan, dan koperasi, termasuk kegiatan sektor informal.

Ketiga, Masyarakat Madani atau Civil Society: Kelompok masyarakat dalam konteks kenegaraan

${ }^{17}$ Kasman Abdullah, "Penyelenggaraan Pemerintahan Dalam Konsep Good Governance", Jurnal Meritokrasi, Vol. 1 No. 1, Makassar, 2002, h. 69. pada dasarnya berada di antara atau di tengahtengah antara pemerintah dan perseorangan, yang mencakup baik perseorangan maupun kelompok masyarakat yang berinteraksi secara sosial, politik, dan ekonomi. ${ }^{18}$

Menurut Jimly Asshiddiqie bahwa dalam sistem negara modern yang berdasar pada supremasi hukum dan konstitusi, negara, pasar, dan masyarakat madani harus berada dalam kedudukan yang harus seimbang, dan berada dalam hubungan sinergis dan secara fungsional saling menunjang. Akan tetapi, pembedaan di antara ketiganya dianggap penting sehingga ketiganya tidak saling mengintervensi ke dalam urusan masing-masing. Ketiga wilayah atau domain kekuasaan itu mempunyai logika dan hukum-hukumnya sendiri. Ketiganya diidealkan harus berjalan seiring dan sejalan, sama-sama kuat dan sama-sama saling mengendalikan satu sama lain, tetapi tidak boleh saling mencampuri atau dicampuradukkan. ${ }^{19}$

Menurut Miftah Thoha ${ }^{20}$ bahwa selain dari komponen pemerintah, swasta, dan rakyat, satu komponen yang amat menentukan untuk melahirkan tata kepemerintahan yang baik adalah moral. Moral menghubungkan dan bertaut erat pada ketiga komponen tersebut yang saling berinteraksi menciptakan tata kepemerintahan yang baik. Moral merupakan operasionalisasi dari sikap dan pribadi seseorang yang beragama. Ajaran agama melekat pada pribadi-pribadi yang berada pada ketiga komponen tersebut. Dengan melaksanakan ajaran agamanya pada masing-masing komponen tersebut, maka moral masing-masing pelaku akan berperan besar sekali dalam menciptakan tata pemerintahan yang baik. Terdapat empat unsur atau prinsip utama yang dapat memberi gambaran administrasi publik yang berciri kepemerintahan yang baik yaitu sebagai berikut:

Pertama, Akuntabilitas: Adanya kewajiban bagi aparatur pemerintah untuk bertindak selaku penanggungjawab dan penanggunggugat atas segala tindakan dan kebijakan yang ditetapkannya.

${ }^{18}$ Sedarmayanti, Good Governance (Kepemerintahan Yang Baik), Bagian Kedua, Mandar Maju, Bandung, 2004, h. 38.

${ }^{19}$ Jimly Asshiddiqie, Format Kelembagaan Negara dan Pergeseran Kekuasaan Dalam UUD 1945, FH UII Press, Yogyakarta, 2005, h. 43.

${ }^{20}$ MiftahThoha, Birokrasi dan Politik di Indonesia, Raja Grafindo Persada, Jakarta, 2004, h. 72. 
Kedua, Transparansi: Kepemerintahan yang baik akan bersifat transparan terhadap rakyatnya, baik di tingkat pusat maupun daerah.

Ketiga, Keterbukaan: Menghendaki terbukanya kesempatan bagi rakyat untuk mengajukan tanggapan dan kritik terhadap pemerintah yang dinilainya tidak transparan.

Keempat, Aturan hukum: Kepemerintahan yang baik mempunyai karakteristik berupa jaminan kepastian hukum dan rasa keadilan masyarakat terhadap setiap kebijakan publik yang ditempuh.

Dalam Pasal 3 Undang-Undang Nomor 28 Tahun 1999 tentang Penyelenggara Negara Yang Bersih dan Bebas Dari Kolusi, Korupsi, dan Nepotisme menyatakan bahwa Asas-Asas Umum Penyelenggaraan Negara meliputi Asas Kepastian Hukum; Asas Tertib Penyelenggaraan Negara; Asas Kepentingan Umum; Asas Keterbukaan; Asas Proporsionalitas; Asas Profesionalitas; dan Asas Akuntabilitas.

Membicarakan tentang tata pemerintahan Indonesia di daerah adalah sangat penting dalam rangka mengetahui keseluruhan Tata Pemerintahan NKRI. Selain itu, untuk mengetahui sejarah proses perjalanan pemerintahan daerah yang sudah pernah diterapkan sejak Indonesia Merdeka hingga sekarang, apakah mempunyai makna terhadap kemajuan bangsa atau malah mempersulit percepatan pembangunan yang telah direncanakan oleh Pemerintah Pusat/ Daerah.

Tujuan pemerintah memilih konsep desentralisasi adalah untuk lebih mempercepat tercapainya kesejahteraan masyarakat. Memang, persoalan otonomi daerah dapat dikatakan cukup kompleks dan banyak dimensi, karena tidak hanya menyangkut persoalan hukum dan pemerintahan saja, tetapi juga terkait aspek ekonomi, sosial, politik, budaya, hankam, dan bidang lainnya. Saat ini, tantangan implementasi otonomi daerah cukup menantang. Ke depan, fokus penyelenggaraan otonomi tidak hanya menekankan pada prinsip-prinsip demokrasi, peningkatan peran serta masyarakat, tetapi juga menciptakan pemerataan keadilan dan kesejahteraan.

Dalam Pasal 1 angka 7 Undang-Undang Nomor 32 Tahun 2004 dijelaskan bahwa Desentralisasi adalah penyerahan wewenang pemerintahan oleh Pemerintah kepada daerah otonom untuk mengatur dan mengurus urusan pemerintahan dalam sistem
NKRI. Soenobo Wirjosoegito memberikan definisi sebagai berikut: Desentralisasi adalah penyerahan wewenang oleh badan-badan umum yang lebih tinggi kepada badan-badan umum yang lebih rendah untuk secara mandiri dan berdasarkan pertimbangan kepentinga sendiri mengambil keputusan pengaturan dan pemerintahan, serta struktur wewenang yang terjadi dari itu.

DWP. Ruiter mengungkapkan bahwa desentralisasi terjadi dalam 2 (dua) bentuk, yaitu desentralisasi teritorial dan fungsional, yang dijabarkan sebagai berikut: Pertama, Desentralisasi teritorial adalah memberi kepada kelompok yang mempunyai batas-batas teritorial suatu organisasi tersendiri, dengan demikian memberi kemungkinan suatu kebijakan sendiri dalam sistem keseluruhan pemerintahan. Kedua, Desentralisasi fungsional adalah memberi kepada suatu kelompok yang terpisah secara fungsional suatu organisasi sendiri, dengan demikian memberi kemungkinan akan suatu kebijakan sendiri dalam rangka sistem pemerintahan. $^{21}$

Desentralisasi atau pendesentralisasian pemerintahan merujuk pada suatu upaya restrukturisasi atau reorganisasi dari kewenangan yang yang menciptakan tanggung jawab bersama di antara lembaga-lembaga di dalam pemerintahan, baik di tingkat pusat, regional maupun lokal sesuai dengan prinsip saling menunjang yang diharapkan pada akhirnya adalah suatu kualitas dan efektifitas keseluruhan dari sistem pemerintahan tersebut termasuk peningkatan kewenangan dan kemampuan dari pemerintahan di tingkat lokal. Desentralisasi bukan sekedar memindahkan sistem politik dan ekonomi yang lama dari pusat ke daerah, tetapi pemindahan tersebut harus pula disertai oleh perubahan kultural menuju arah yang lebih demokratis dan beradab. Melalui desentralisasi diharapkan akan meningkatkan peluang masyarakat untuk berpartisipasi dalam proses pengambilan kebijakan yang terkait dengan masalah sosial, politik, ekonomi. Hal ini sangatlah dimungkinkan karena karena fokus pengambilan keputusan menjadi lebih dekat dengan masyarakat. Melalui proses ini maka desentralisasi diharapkan akan mampu meningkatkan penegakan hukum, meningkatkan efisiensi dan efektifitas pemerintah, dan sekaligus meningkatkan

${ }^{21}$ Ibid. 
daya tanggap, transparansi dan akuntabilitas pemerintah daerah.

Dengan demikian, sistem desentralisasi mengandung makna pengakuan penentu kebijaksanaan pemerintah terhadap potensi dan kemampuan daerah dengan melibatkan wakilwakil rakyat di daerah dengan menyelenggarakan pemerintahan dan pembangunan, dengan melatih diri menggunakan hak yang seimbang dengan kewajiban masyarakat yang demokratis.

Robert Reinowmengatakan bahwa ada 2 (dua) alasan pokok dari kebijaksanaan membentuk pemerintahan di daerah. Pertama, membangun kebiasaan agar rakyat memutuskan sendiri sebagian kepentingannya yang berkaitan langsung dengan mereka. Kedua, memberi kesempatan kepada masingmasing komunitas yang mempunyai tuntutan yang bermacam-macam untuk membuat aturan-aturan dan programnya sendiri. ${ }^{22}$

Ada beberapa hal yang hendak dicapai dari maksud konsep desentralisasi ini, antara lain: Dengan otonomi daerah diharapkan kesejahteraan rakyat lebih tercipta dan untuk penguatan demokrasi lokal; Dengan otonomi daerah diharapkan pemerintah daerah bisa memberikan pelayanan publik yang lebih optimal; Dengan otonomi daerah diharapkan pemerintah daerah mempunyai program pembangunan dan rencana kerja sesuai dengan kebutuhan masyarakat; Dengan otonomi daerah diharapkan dapat menciptakan Tata Kelola Pemerintah yang Baik.

Konsep di atas mempertegas bahwa konsep otonomi daerah adalah untuk menciptakan tata kelola pemerintahan yang baik. Tata kelola pemerintahan yang baik itu sejatinya adalah zero corruption. Korupsi itu awal bencana daerah karena membuat kinerja pemerintahan daerah menjadi buruk. Tata kelola keuangan yang baik itu idealnya uang rakyat jatuh ke rakyat dalam program-program yang pro rakyat. Ini memang menjadi problem dalam desentralisasi. Tetapi, dengan perjalanan waktu dan pembimbingan mestinya hal itu bisa diatasi.

Saat ini, kepala daerah sudah berpacu bagaimana mengelola daerah dengan prinsip akuntabilitas dan transparansi sebagai bentuk perwujudan tata pemerintahan yang baik atau good governance. Satu lagi penghambat penerapan good governance

22 Ibid adalah reformasi birokrasi di daerah yang belum berjalan mulus. Kalau mau menciptakan tata kelola pemerintahan yang baik, birokrasinya harus direformasi terlebih dahulu, mulai dari kelembagaan yang efisien, tidak perlu membentuk lembaga jika tidak ada urgensinya. Sekarang masih terdapat daerah yang organisasinya gemuk sehingga menyedot tenaga aparatur dan seenaknya mengangkat aparatur. Imbas dari birokrasi yang gemuk adalah APBD habis untuk belanja aparatur ketimbang untuk pembangunan/ belanja publik.

Pola hubungan antar tingkat pemerintahan, khususnya antara provinsi dan kabupaten/kota dianggap penting karena menyangkut efektifitas kinerja pemerintahan dalam melayani masyarakatnya. Gubernur dituntut untuk mengimplementasikan Rencana Pembangunan Jangka Menengah Daerah (RPJMD), khususnya menyangkut targettarget yang telah ditetapkan. Tidak mungkin hal tersebut dapat dilakukan tanpa dukungan dan kerjasama dari kabupaten/kota. Hal ini tentu saja dapat terwujud apabila tercipta suatu kondisi yang harmoni (seiring-sejalan) antara provinsi dan kabupaten/kota dalam hal pelaksanaan pembangunan. Dalam proses penyusunan rencana atau perencanaan, maka alur yang wajar adalah dari bawah ke atas atau bottom up, tetapi kalau dalam hal pelaksanaan pembangunan, prosesnya adalah dari atas ke bawah atau top down. Dengan kata lain bahwa harus diciptakan suatu mekanisme tersendiri yang mengikat secara hierarki menyangkut pelaksanaan pembangunan.

Perspektif Undang-Undang Pemerintah Daerah jika kita mencermati Undang-Undang Nomor 32 Tahun 2004 tentang Pemerintahan Daerah dapat dilihat jelas bahwa hubungan pemerintah, pemerintah daerah provinsi dan kabupaten/kota memang mengalir dari pusat ke daerah. Dalam Pasal 2 ayat (4) menjelaskan bahwa pemerintahan daerah dalam menyelenggarakan urusan pemerintahan memiliki hubungan dengan pemerintah dan dengan pemerintahan daerah lainnya. Kemudian dalam ayat (7) menjelaskan pula bahwa hubungan wewenang, keuangan, pelayanan umum, pemanfaatan sumber daya alam, dan sumber daya lainnya menimbulkan hubungan administrasi dan kewilayahan antar susunan pemerintahan.

Selanjutnya dalam Bab III tentang Pembagian Urusan Pemerintahan khususnya Pasal 13 dan 14 
disebutkan bahwa nyaris tidak ada bedanya antara urusan pemerintahan provinsi dan kabupaten/ kota sebagaimana telah dijelaskan pada bagian sebelumnya. Ini artinya bahwa pelaksanaan urusan pemerintahan didasarkan pada tingkat pemerintahannya. Pada pasal itu disebutkan bahwa urusan wajib yang menjadi kewenangan pemerintah daerah provinsi merupakan urusan dalam skala provinsi sedangkan urusan wajib yang menjadi kewenangan pemerintah daerah kabupaten/kota merupakan urusan yang berskala kabupaten/kota.

Provinsi dan kabupaten/kota itu sudah seharusnya bekerjasama dan saling berkoordinasi. Hal ini diharuskan karena objek pembangunannya sama, wilayah administrasinya juga sama, masyarakat yang diayominya juga sama. Sesuai UndangUndang Nomor 22 Tahun 1999 jo. Undang-Undang Nomor 32 Tahun 2004, kewenangan pemerintah pusat yang ditetapkan memang sedikit tetapi mendasar dan strategis, sedangkan kewenangan daerah ditetapkan lebih besar. Daerah kabupaten/ kota merupakan penerima kewenangan terbesar, sedangkan daerah provinsi menerima kewenangan yang sifatnya koordinasi, pengawasan, dan pembinaan. Dasar pemikirannya adalah bahwa kabupaten/kota merupakan unit pemerintahan yang bersentuhan langsung dengan masyarakat, yakni langsung melayani masyarakat. Oleh karena itu, bobot kewenangan harus dititikberatkan pada unit pemerintahan ini, bukan pada provinsi. Provinsi diberi kewenangan melakukan koordinasi antar kabupaten/kota yang berada di bawah koordinasinya. Di samping itu, sebagai wakil pemerintah pusat di daerah, Gubernur juga diberi kewenangan untuk melakukan pengawasan dan pembinaan terhadap kabupaten/kota yang berada di lingkup wilayah provinsinya.

Berdasarkan Undang-Undang Nomor 22 Tahun 1999 jo. Undang-Undang Nomor 32 Tahun 2004, pemerintah provinsi menganut asas dekonsentrasi sekaligus desentralisasi. Berdasarkan asas dekonsentrasi, maka provinsi merupakan wilayah administrasi, sedangkan berdasarkan asas desentralisasi, maka provinsi menjadi daerah otonom. Implikasinya secara struktural adalah menjadikan provinsi sebagai wilayah administrasi sekaligus sebagai wilayah otonom.
Sebagai wilayah administrasi, provinsi menerima kebijakan politik dari pemerintah pusat. Kebijakan tersebut dilaksanakan oleh Gubernur sebagai kepala wilayah administrasi. Pada konteks ini Gubernur bertindak atas nama pemerintah pusat, bukan atas nama kepala daerah otonom. Dalam hubungannya dengan pemerintah kabupaten/kota, Pasal 3 Peraturan Pemerintah Nomor 23 Tahun 2011 tentang Perubahan Atas Peraturan Pemerintah Nomor 19 Tahun 2010 tentang Tata Cara Pelaksanaan Tugas dan Wewenang Serta Kedudukan Keuangan Gubernur Sebagai Wakil Pemerintah di wilayah provinsi menjelaskan bahwa, Gubernur sebagai wakil pemerintah memiliki tugas melaksanakan urusan pemerintahan meliputi:

Pertama, koordinasi penyelenggaraan pemerintahan antara pemerintah daerah provinsi dengan instansi vertikal, dan antar instansi vertikal di wilayah provinsi yang bersangkutan; kedua, koordinasi penyelenggaraan pemerintahan antara pemerintah daerah provinsi dengan pemerintah daerah kabupaten/kota di wilayah provinsi yang bersangkutan; ketiga, koordinasi penyelenggaraan pemerintahan antar pemerintahan daerah kabupaten/ kota di wilayah provinsi yang bersangkutan; keempat, koordinasi dalam penyusunan, pelaksanaan dan pengendalian serta evaluasi dalam rangka sinkronisasi Rencana Pembangunan Jangka Panjang Daerah (RPJPD), Rencana Pembangunan Jangka Menengah Daerah (RPJMD), dan Rencana Kerja Pemerintah Daerah (RKPD) kabupaten dan kota agar mengacu pada RPJPD, RPJMD, dan RKPD Provinsi serta Rencana Pembangunan Jangka Panjang Nasional (RPJPN), Rencana Pembangunan Jangka Menengah Nasional (RPJMN), dan Rencana Kerja Pemerintah (RKP) serta kebijakan pembangunan nasional yang ditetapkan oleh pemerintah; kelima, koordinasi pembinaan dan pengawasan penyelenggaraan tugas pembantuan di daerah provinsi dan kabupaten/ kota; keenam, pembinaan dan pengawasan penyelenggaraan pemerintahan daerah kabupaten/ kota; ketujuh, menjaga kehidupan berbangsa dan bernegara serta memelihara keutuhan NKRI; kedelapan, menjaga dan mengamalkan ideologi Pancasila dan kehidupan demokrasi; kesembilan, memelihara stabilitas politik; dan kesepuluh, menjaga etika dan norma penyelenggaraan pemerintahan di daerah. 
Selain melaksanakan urusan pemerintahan sebagaimana dimaksud pada ayat (1), Gubernur sebagai wakil Pemerintah juga melaksanakan urusan pemerintahan di wilayah provinsi yang menjadi kewenangan pemerintah sesuai dengan ketentuan peraturan perundang-undangan.

Dalam hal provinsi sebagai daerah otonom, maka pemerintah kabupaten/kota bukanlah bawahan dari provinsi. Tetapi pada konteks provinsi dalam kedudukannya sebagai wilayah administrasi, maka pemerintah kabupaten/kota adalah bawahannya di mana pemerintah kabupaten/kota adalah subordinat wilayah administrasi provinsi. Hubungan provinsi dengan kabupaten/kota adalah sesama daerah otonom dalam hubungan koordinasi. Jadi bukan hubungan hierarki antara atasan dengan bawahan.

Hal ini berimplikasi pula pada kedudukan Gubernur dan Bupati/Walikota. Dalam hal Gubernur sebagai kepala daerah otonom, maka Bupati/Walikota bukanlah bawahan dari Gubernur. Tetapi pada konteks Gubernur dalam kedudukannya sebagai kepala wilayah administrasi, maka Bupati/Walikota adalah bawahannya. Hubungan Gubernur dengan Bupati/Walikota adalah sesama kepala daerah otonom dalam hubungan koordinasi. Jadi bukan hubungan hierarki antara atasan dengan bawahan.

Sebagaimana halnya provinsi, kabupaten/ kota juga menerima tugas pembantuan dari pmerintah atasnya, yakni dari pemerintah pusat dan pemerintah provinsi. Tugas pembantuan yang diberikan pemerintah kepada kabupaten/kota meliputi sebagian tugas politik luar negeri, pertahanan dan keamanan, peradilan, moneter dan fiskal, agama, dan kewenangan lainnya seperti kebijakan tentang perencanaan nasional dan pengendalian pembangunan secara makro, dana perimbangan keuangan, sistem administrasi negara dan lembaga perekonomian negara, pembinaan dan pemberdayaan sumber daya manusia, pendayagunaan sumber daya alam serta teknologi tinggi yang strategis, konservasi dan standardisasi nasional.

Sedangkan tugas pembantuan yang diberikan provinsi sebagai daerah otonom kepada kabupaten/ kota meliputi sebagian tugas dalam bidang pemerintahan dalam bidang tertentu lainnya, termasuk juga sebagian tugas pemerintahan yang tidak atau belum dapat dilaksanakan oleh kabupaten/kota. Adapun tugas pembantuan yang diberikan provinsi sebagai wilayah administrasi kepada kabupaten/kota mencakup sebagian tugas dalam bidang pemerintahan yang dilimpahkan kepada Gubernur sebagai wakil pemerintah. Jadi tugas pembantuan yang diberikan kepada kabupaten/kota adalah kewenangan yang merupakan kompetensi pemerintah pusat dan pemerintah provinsi (baik sebagai daerah otonom maupun administrasi).

Untuk mencari konfigurasi pola hubungan antara Gubernur dengan Bupati/Walikota, penulis mencoba menganalogikannya dengan pola hubungan antara pusat dengan provinsi, dalam hal ini membandingkan pelaksanaan dekonsentrasi yang dilimpahkan oleh pusat kepada provinsi (Gubernur), di mana setiap kementerian/lembaga mempunyai agenda program (sesuai Renstra masing-masing) yang pelaksanaannya dilimpahkan ke provinsi.

Pasal 10 ayat (5) Undang-Undang Nomor 32 Tahun 2004 menegaskan bahwa beberapa pola hubungan yang bersifat hubungan atasan-bawahan antara pemerintah pusat dengan pemerintah daerah yang dapat diuraikan sebagai berikut: Dalam urusan pemerintahan yang menjadi kewenangan pemerintah di luar urusan pemerintahan yang menjadi kewenangan pemerintah pusat, pemerintah dapat: Menyelenggarakan sendiri sebagian urusan pemerintahan; Melimpahkan sebagian urusan pemerintahan kepada Gubernur selaku wakil Pemerintah; atau Menugaskan sebagian urusan kepada pemerintahan daerah dan/atau pemerintahan desa berdasarkan asas tugas pembantuan.

Pola sebagaimana dipaparkan di atas dapat diterjemahkan ke dalam pola hubungan antara Provinsi dengan kabupaten/kota yang dalam hal ini dibebankan kepada Gubernur dan Bupati/kepala daerah. Jika melihat gambar di atas, ada urusan pemerintahan yang mutlak adalah urusan pemerintah pusat dan ada beberapa urusan pemerintahan yang menjadi urusan bersama antara pemerintah pusat dengan daerah, baik provinsi maupun kabupaten/ kota. Pola pembagian urusan pemerintahan ini jika kemudian diejawantahkan ke dalam pola hubungan provinsi dengan kabupaten/kota, maka tentunya tidak akan berbeda jauh. Urusan pemerintahan yang merupakan urusan mutlak provinsi terhadap kabupaten/kota sebagaimana termaktub dalam Pasal 3 Peraturan Pemerintah Nomor 23 Tahun 2011 sebagaimana telah dijelaskan sebelumnya. Sedangkan 
urusan pemerintahan yang menjadi urusan bersama tetap mengadopsi pola hubungan pusat dengan daerah.

Pola hubungan kerjasama yang seperti ini berimplikasi pada penggunaan anggaran negara, baik APBN maupun APBD. Pada dasarnya, dalam konsep dekonsentrasi, setiap dinas provinsi atau UPT pusat yang menerima dekonsentrasi diberikan kekuasaan untuk menyusun anggarannya sesuai kebutuhan daerahnya dengan acuan program, indikasi kegiatan, dan besaran anggaran yang sudah ditentukan oleh pusat. Dengan pola seperti itu, maka secara otomatis tercipta hubungan yang melembaga antara pemerintah pusat dengan unit organisasi di bawahnya. Andai saja tidak ada mekanisme dekonsentrasi seperti ini mungkin saja akan sulit juga bagi pemerintah pusat untuk menitipkan agenda programnya di daerah. Selain itu, pola hubungan kelembagaan juga diyakini tidak akan berjalan secara mulus karena memang secara struktural dinas provinsi tidak langsung berada di bawah kementerian atau lembaga tertentu di pusat.

Pola penganggaran yang demikian ini juga dapat diejawantahkan ke dalam pola hubungan kerjasama antara provinsi dengan kabupaten/kota. Dengan pola penganggaran yang seperti ini, maka pemerintah provinsi dapat pula menitipkan agenda programnya di kabupaten/kota sehingga dapat menghemat APBD.

Kalau melihat mekanisme penganggaran sesuai aturan keuangan negara dan pemerintahan daerah, maka model yang paling sesuai untuk dilaksanakan adalah dengan Tugas Pembantuan provinsi ke kabupaten/kota atau desa. Hal ini sesuai dengan ketentuan bahwa yang dimaksud dengan Tugas Pembantuan adalah penugasan dari pemerintah kepada daerah dan/atau desa, dari pemerintah provinsi kepada kabupaten/kota dan/atau desa serta dari pemerintah kabupaten/ kota kepada desa untuk melaksanakan tugas tertentu. Pelaksanaan Tugas Pembantuan dalam pelaksanaan APBD provinsi ini tentunya harus mendapat dukungan dari legislatif (DPRD) karena memang harus dituangkan ke dalam Perda APBD.

Pada pelaksanaan Tugas Pembantuan ini Pemerintah Provinsi mempunyai alokasi anggaran untuk ditugas pembantuankan ke kabupaten/kota dan/atau desa melalui setiap SKPD masing-masing. Alokasi anggaran dimaksud untuk membiayai pelaksanaan program-program provinsi yang bersifat khusus (tertentu). Ada beberapa alasan kenapa model Tugas Pembantuan dari provinsi ke kabupaten/kota atau desa ini perlu diterapkan: pertama, Dengan Tugas Pembantuan ini, maka pelaksanaan programprogram provinsi di kabupaten/kota diharapkan dapat seiring sejalan sesuai target yang ditetapkan; kedua, Akan tercipta hubungan yang melembaga lebih kuat antara SKPD di tingkat provinsi dengan SKPD di tingkat kabupaten/kota; ketiga, Bantuan Langsung Masyarakat (BLM) dapat juga di tugas pembantuankan; keempat, Tercipta keterpaduan perencanaan antara provinsi dan kabupaten/kota.

Untuk dapat menerapkan konsep di atas, tentunya setiap SKPD provinsi harus sudah siap dengan mekanisme pengaturan tugas pembantuan berdasarkan sektornya masing-masing. Tim Anggaran Pemerintah Daerah (TAPD) bersama-sama dengan Panitia Anggaran Legislatif dalam hal ini menentukan besarnya alokasi anggaran bagi pelaksanaan tugas pembantuan di kabupaten/kota, sementara mekanisme penggunaan dananya diserahkan kepada setiap SKPD terkait.

Dengan dilaksanakannya pola hubungan yang seperti demikian itu, maka hubungan kerjasama antara Gubernur dengan Bupati/Walikota atau antara provinsi dengan kabupaten/kota dapat berjalan dengan optimal, sinergis, dan berkesinambungan. Terkhusus mengenai anggaran pelaksanaan kegiatan maupun urusan pemerintahan lainnya, dengan pola hubungan kerjasama seperti yang telah dijelaskan di atas, maka tentunya dapat mengefektifkan, mengefisiensikan, serta mengoptimalkan penggunaan anggaran pendapan dan belanja negara maupun daerah. Dengan pola hubungan ini, tentu saja perwujudan good governance dapat diwujudkan sesuai dengan cita-cita dan tujuan negara.

\section{Penataan Kelembagan Yang Dapat Mensinergikan Hubungan Kewenangan Pemerintahan Yang Efektif Antara Pemerintah Provinsi Dengan Pemerintah Kabupaten/Kota}

Hubungan antara Pemerintah Daerah Provinsi dengan Pemeritah Kabupaten/Kota tidak lagi sebagai hubungan hirarki yang berjenjang, tapi masingmasing berkedudukan sebagai daerah otonom. Begitu pula dalam distribusi dan alokasi kewenangan antara Pemerintah Daerah Provinsi dengan Kabupaten/ 
Kota, mengalami pergeseran dan perubahan jika dibandingkan dengan ketentuan sebelumnya. ${ }^{23}$

Dengan adanya perubahan dalam kewenangan bagi daerah provinsi dan kabupaten/kota tersebut, pada giliran berikutnya akan dituntut mengadakan perubahan atau penataan ulang kelembagaan di Daerah. Struktur kelembagaan yang baik, selayaknya sesuai dengan kewenangan yang dimiliki dan beban kerja yang ada. Namun dalam penerapannya di lapangan tidak semudah yang dibayangkan, pola pikir birokrasi dan kepentingan birokrat yang sangat menonjol menghasilkan kelembagaan yang belum sesuai dengan yang diharapkan.

Kelembagaan pemerintah daerah yang rasional yaitu Kelembagaan yang sesuai dengan kebutuhan daerahnya bukan kebutuhan dari birokrat atau politisi daerah. Kelembagaan yang rasional, efisien, efektif dan profesional sesuai dengan kebutuhan perlu dikedepankan sehingga kelembagaan pemerintah daerah yang kelak terbentuk tidak menjadi beban, baik bagi pemerintah itu sendiri maupun bagi masyarakat yang mendapatkan layanannya.

Berkaitan dengan model pembagian urusan pemerintahan sebagaimana telah dipaparkan sebelumnya, perlu ada konsistensi urusan pemerintahan yang ditangani oleh birokrasi di tingkat nasional. Pemerintah pusat lebih banyak menangani urusan yang bersifat kebijakan, standar, norma, prosedur, dan kriteria, serta melakukan melakukan pembinaan pembinaan dan pengawasan pengawasan secara terus menerus. Pemerintah pusat juga perlu lebih banyak melakukan kegiatan yang bersifat outward looking untuk membangun wibawa di ranah internasional, tidak lagi mengurusi kegiatan yang bersifat teknis operasional, kecuali untuk urusan yang masih menjadi kewenangan mutlak pemerintah pusat.

Dalam membangun sebuah struktur pemerintahan daerah, maka yang perlu diperhatikan adalah kebutuhan daerah dengan melihat obyek yang di urus, bukan subyek yang mengurus. Obyek yang di urus adalah masyarakat dengan segala kegiatannya. Hal ini juga akan berkaitan dengan urusan wajib dan urusan pilihan dari masing-masing daerah yang sudah ditetapkan melalui Perda sebagai sebuah kontrak

${ }^{23}$ Kebijakan otonomi daerah yang digulirkan semenjak berlakunya UU Nomor 22 Tahun 1999 tentang Pemerintahan Daerah yang kemudian di revisi dengan UU Nomor 32 Tahun 2004 telah membawa banyak perubahan pada sistem pemerintahan di daerah. sosial. Sedangkan subyek yang mengurus adalah birokrasi pemerintah, yang dari waktu ke waktu pangkatnya semakin tinggi sehingga memerlukan organisasi yang lebih besar dan eselon yang lebih tinggi, yang pada gilirannya mendesak waktu pangkatnya semakin tinggi sehingga memerlukan organisasi yang lebih besar dan eselon yang lebih tinggi, yang pada gilirannya mendesak terbangunnya birokrasi yang besar. Hal ini terjadi apabila tidak dikembangkan organisasi fungsional yang dapat menampung tuntutan kenaikan jabatan dan pangkat ke dalam pekerjaan yang lebih profesional sepanjang hayat atau life long career.

Banyaknya persoalan kewenangan antar pemerintahan yang terjadi dalam implementasi otonomi daerah, khususnya antara Gubernur dengan Bupati/Walikota, menyebabkan perlu adanya pemikiran yang inovatif dalam merestrukturisasi kelembagaan dalam pelaksanaan otonomi daerah untuk mewujudkan tata pemerintahan yang baik. Sebagaimana telah dijelaskan sebelumnya bahwa otonomi daerah lebih banyak dibebankan kepada kabupaten/kota sebagai daerah otonom, sedangkan provinsi ditempatkan sebagai wilayah administrasi dan juga sekaligus sebagai daerah otonom. Provinsi diposisikan sebagai intermediate government yang merupakan penyambung dan penghubung kepentingan serta kewenangan yang bersifat nasional dengan yang bersifat lokal. Kedudukan Gubernur pada konteks ini ditempatkan sebagai wakil pemerintah pusat di daerah sekaligus pula sebagai kepala daerah otonom.

Pembahasan masalah eksistensi Gubernur tidak lepas dari konsepsi pemerintahan secara keseluruhan. Harus dipahami, pemerintahan daerah merupakan subsistem dari sistem pemerintahan negara secara keseluruhan, seperti yang dicantumkan dalam Pasal 4 ayat (1) UUD 1945 menegaskan bahwa Presiden Republik Indonesia memegang kekuasaan pemerintahan menurut Undang-Undang Dasar. Dalam pelaksanaannya, pemerintah pusat bisa melaksanakannya dengan cara sentralisasi (pemusatan kekuasaan) atau desentralisasi. Dalam kaitan dengan pemerintahan otonom, desentralisasi hanya mencakup pemencaran kekuasaan di bidang otonomi. Posisi Gubernur dalam konteks ini, sebagaimana telah dijelaskan sebelumnya, ada 2 (dua) kedudukan, yaitu sebagai Kepala Daerah Otonom yang kewenangannya 
atas delegasi ${ }^{24}$ dan sebagai wakil pemerintah pusat di daerah yang jelas sekali kewenangannya atas dasar mandat ${ }^{25}$ karena kewenangannya mewakili pusat dan atas kedudukannya sebagai wakil pemerintah pusat didaerah, Gubernur harus bertanggungjawab kepada Presiden.

Kedudukan Gubernur sebagai wakil pemerintah di daerah memiliki fungsi pembinaan, pengawasan dan koordinasi urusan pemerintahan di daerah serta tugas pembantuan. Dari sini bisa dilihat bahwa dalam pelaksanaan otonomi daerah Gubernur sebagai wakil pemerintah pusat di daerah memiliki kewenangan dalam melakukan pembinaan, pengawasan dan koordinasi urusan pemerintah di daerah.

Dalam pelaksanaan peran Gubernur sebagai wakil pemerintah pusat, maka hubungan antara Gubernur dengan Bupati/Walikota bersifat bertingkat di mana Gubernur dapat melakukan peran pembinaan dan pengawasan terhadap penyelenggaraan pemerintahan daerah. Sebaliknya Bupati/Walikota dapat melaporkan permasalahan yang terjadi dalam penyelenggaraan pemerintahan di daerah, termasuk dalam hubungan antar kabupaten/kota.

Berdasarkan asas dekonsentrasi, maka provinsi merupakan wilayah administrasi, sedangkan berdasarkan asas desentralisasi, maka provinsi menjadi daerah otonom. Dalam hal provinsi sebagai daerah otonom, maka pemerintah kabupaten/kota

${ }^{24}$ Kewenangan Delegatif merupakan kewenangan yang bersumber dari pelimpahan suatu organ pemerintahan kepada organ lain dengan dasar peraturan perundang-undangan. Berbeda dengan kewenangan mandat, dalam kewenangan delegatif tanggung jawab dan tanggung gugat beralih kepada yang diberi limpahan wewenang tersebut atau beralih pada delegataris. Dengan begitu, si pemberi limpahan wewenang tidak dapat menggunakan wewenang itu lagi kecuali setelah ada pencabutan dengan berpegang pada azas contrarius actus. Oleh sebab itu, dalam kewenangan delegatif peraturan dasar berupa peraturan perundang-undangan merupakan dasar pijakan yang menyebabkan lahirnya kewenangan delegatif tersebut. Tanpa adanya peraturan perundang-undangan yang mengatur pelimpahan wewenang tersebut, maka tidak terdapat kewenangan delegatif. Lihat Lutfi Effendi, Pokok-Pokok Hukum Administrasi, Bayumedia Publishing, Malang, 2004, h. 77-79.

${ }^{25}$ Kewenangan Mandat merupakan kewenangan yang bersumber dari proses atau prosedur pelimpahan dari pejabat atau badan yang lebih rendah. Kewenangan mandat terdapat dalam hubungan rutin atasan bawahan, kecuali bila dilarang secara tegas. Kemudian, setiap saat si pemberi kewenangan dapat menggunakan sendiri wewenang yang dilimpahkan tersebut. Untuk mengetahui secara tepat bentuk perbuatan pemerintahan yang dilakukan atas dasar wewenang mandat dapat dilihat dari tanda atas nama (a.n.) ataupun tanda untuk beliau (u.b.). Lihat Lutfi Effendi, Ibid. bukanlah bawahan dari provinsi. Tetapi pada konteks provinsi dalam kedudukannya sebagai wilayah administrasi, maka pemerintah kabupaten/kota adalah bawahannya di mana pemerintah kabupaten/ kota adalah subordinat wilayah administrasi provinsi. Hubungan provinsi dengan kabupaten/kota adalah sesama daerah otonom dalam hubungan koordinasi. Jadi bukan hubungan hierarki antara atasan dengan bawahan. Dalam hal Gubernur sebagai kepala daerah otonom, maka Bupati/Walikota bukanlah bawahan dari Gubernur. Tetapi pada konteks Gubernur dalam kedudukannya sebagai kepala wilayah administrasi, maka Bupati/Walikota adalah bawahannya.

Berdasarkan pemahaman di atas, maka sangat pantaslah untuk kemudian melakukan rekonstruksi penataan kelembagaan dalam rangka pelaksanaan otonomi daerah untuk mewujudkan tata pemerintahan yang baik. Penataan kelembagaan yang dimaksud disini adalah reposisi kedudukan Gubernur. Peraturan Pemerintah Nomor 23 Tahun 2011 telah memberikan penegasan terhadap kedudukan Gubernur sehingga penulis memiliki gagasan konstruksi penataan kelembagaan pemerintahan daerah yang dapat digambarkan sebagai berikut:

\section{Gambar: Konstruksi Penataan Kelembagaan Pemerintahan Daerah}

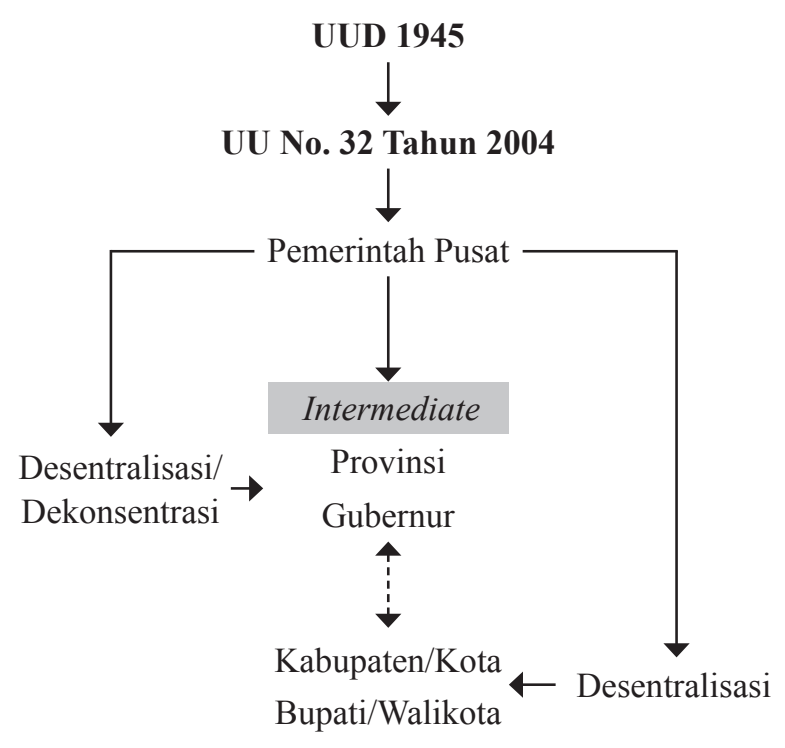

Berdasarkan gambar di atas dapat dipahami bahwa antara pemerintah provinsi dengan pemerintah kabupaten/kota bukanlah hubungan hierarki antara atasan dengan bawahan, begitu pula antara 
Gubernur dengan Bupati/Walikota. Pemerintah Provinsi/Gubernur diposisikan sebagai Intermediate government di mana Pemerintah Provinsi/Gubernur menjadi titik tengah antara pemerintah pusat dengan pemerintah kabupaten/kota.

Peran sebagai kepala daerah otonom dalam relasi horizontal antara Gubernur dengan Bupati/ Walikota praktis merupakan pengalaman baru sehingga berbagai bentuk praksis, yakni dialektika teori dan praktek, tentang hubungan horizontal antar pemerintah selalu dibutuhkan. Untuk sampai pada dialektika itu, upaya-upaya menuju pencapaian suatu tata kelola pemerintahan yang baik perlu dilihat dulu dari tiga persepektif, yakni:

Pertama, Perspektif Internal Organisasi, yakni masing-masing organisasi pemerintah dalam dirinya sendiri bergerak ke arah perubahan untuk kepentingan efisiensi organisasi di sisi input. Ini umumnya mengambil wujud reformasi birokrasi, kepegawaian, administrasi, atau sistem organisasi. Pemerintah, dalam perspektif ini, melayani dirinya sendiri.

Kedua, Perspektif Eksternal Organisasi, yakni pemerintah berhubungan dengan publik atau masyarakat luas dengan menggunakan cara-cara yang dapat meningkatkan efektivitas organisasi di sisi output atau pun outcome. Bentuknya dapat dilihat dari reformasi pelayan sosial dan ekonomi seperti penyediaan infrastruktur kebutuhan dasar, perijinan, dan lain-lain, dengan suatu standar tertentu. Dalam perspektif ini, pemerintah melayani publik sebagai pihak di luar organisasi.

Ketiga, Perspektif Antara, yakni hubungan antar sesama organisasi pemerintah yang berorientasi pada pemenuhan kebutuhan bersama melalui pembangunan konsensus, complementarity with embeddedness, atau pun coproduction, yang pada prinsipnya merupakan tindakan-tindakan kolektif berbasis negosiasi. Dalam perspektif ini, suatu organisasi pemerintah melayani organisasi pemerintah yang lain untuk pencapaian tujuan bersama.

Perspektif yang terakhir lebih relavan untuk dijadikan acuan dalam pembentukan hubungan horizontal antar pemerintah karena sejumlah alasan. Sebagaimana telah dijelaskan bahwa provinsi dan kabupaten/kota adalah yurisdiksi-yurisdiksi otonom dalam relasi horizontal, sehingga Gubernur dan Bupati/Walikota adalah mitra yang sejajar. Sebagai mitra sejajar, integrasi provinsi dan kabupaten/kota tidak digerakkan oleh sebuah komando vertikal ataupun dominasi. Selain itu, Perspektif Antara ini sejalan dengan atribut yang melekat pada masing-masing yurisdiksi, yakni setiap yurisdiksi pada prinsipnya memiliki potensi dan kapasitas tertentu yang berbeda (unik) sehingga melahirkan kompetensi yang berbeda (unik) pula. Dalam relasi yang horizontal, potensi, kapasitas, dan kompetensi yang unik ini didayagunakan dalam wujud tindakantindakan kolektif dengan basis negosiasi.

Jika relasi horizontal provinsi dan kabupaten/kota menunjukkan wajah Indonesia yang terdesentralisasi, maka relasi vertikalnya menampilkan Indonesia dalam rupa negara kesatuan. Relasi vertikal pemerintah subnasional ini terjadi manakala Gubernur memainkan perannya sebagai wakil pemerintah pusat. Dalam peran ini Gubernur tidak lain adalah pemerintah pusat di provinsi dan di kabupaten/ kota, sehingga lazim disebut sebagai kepala wilayah administratif untuk membedakannya dari kepala daerah otonom. Disini pemerintah pusat memiliki agenda-agenda dan target-target pembangunan tersendiri yang kemudian didelegasikan, didekonsentrasikan, atau dialirkan sebagai tugas pembantuan kepada Gubernur. Gubernur kemudian mengimplementasikan kekuasaan otoritatif vertikal itu dengan suatu derajat commanding power tertentu.

Sudah barang tentu proses pelaksanaan agendaagenda pemerintah pusat itu dan tingkat pencapaian target-targetnya di daerah ditentukan oleh seberapa jauh Gubernur mampu membina, mengawasi, dan melakukan koordinasi dengan agen-agen daerah dan pusat. Selain itu, pelaksanaan agenda-agenda dan tingkat pencapaian target-target pemerintah pusat ini ditentukan pula oleh seberapa jauh Gubernur mampu memantau, mengevaluasi, serta memberikan rekomendasi atas proses dan hasil interaksi antara instansi-instansi vertikal pusat dengan pemerintah provinsi dan kabupaten/kota, antar instansi vertikal pusat sendiri yang beroperasi di daerah, pemerintah provinsi dengan kabupaten/ kota, serta antar pemerintah kabupaten/kota dalam konteks dekonsentrasi ataupun tugas pembantuan. Oleh karenanya, tugas sebagai wakil pemerintah pusat ini tidak lain adalah tugas mengelola titik temu kepentingan-kepentingan pusat dan daerah. 
Walau begitu, ada banyak kementerian dan lembaga non kementerian yang beroperasi di daerah sehingga tugas mengelola titik temu kepentingan ini sesungguhnya pelik juga. Ada beberapa alasan untuk itu, yakni Pertama, sampai sejauh ini belum tampak pembedaan yang tajam antara organisasi perangkat pendukung Gubernur sebagi wakil pemerintah pusat dengan organisasi perangkat Gubernur sebagai kepala daerah otonom. Dalam format Peraturan Pemerintah Nomor 19 Tahun 2010, operasi harian wakil pemerintah pusat secara ex-officio dikendalikan oleh sekretaris daerah yang ditopang oleh sebuah sekretaris khusus. Format ini menuntut ketentuan yang khusus pula mengenai pendayagunaan aparatur, termasuk juga mengenai pembiayaan atas operasi hariaannya. Dalam hal pendayagunaan aparatur, dualisme sektoral masa lalu antara dinas daerah dan kantor wilayah departemen berpotensi untuk muncul kembali, khususnya jika diingat bahwa selain tugas dekonsentrasi dalam jalur Kementerian Dalam Negeri, ada pula tugas dekonsentrasi yang dilimpahkan melalui jalur lembaga non kementerian yang masing-masing memiliki perangkat institusi (aturan, organisasi, dan tatalaksana) sendiri-sendiri, termasuk Unit-unit Pelaksana Teknis, dan Badanbadan di luar Kementerian.

Kedua, tidak semua undang-undang sektoral sepadan dengan Undang-Undang Pemerintahan Daerah dan aturan turunannya. Hal-hal yang diatur dalam undang-undang sektoral pada prinsipnya kewenangan-kewenangan kementerian maupun lembaga non kementerian di pusat. Jika implementasi di daerah bertabrakan kewenangan-kewenangan yang diatur dalam Undang-Undang Pemerintahan Daerah, konflik regulasi akan bertumpuk di tangan Gubernur. Beberapa contoh tentang ini telah ditelisik dalam, misalnya sektor kehutanan, perkebunan, pertambangan, perairan laut, dan sebagainya. Konflik regulasi, bahkan juga dualisme sektoral yang disebut di atas, menagih pembentukan kerangka hukum yang jauh lebih terintegrasi. Konflik itu tidak cukup diselesaikan sepihak oleh satu undang-undang secara parsial, misalnya Undang-Undang Pemerintah Daerah atau undang-undang sektoral saja. Dengan kata lain, pembentukan kerangka hukum yang lebih terintegrasi akan menjadi agenda desentralisasi yang lebih luas dan lebih panjang dari pada revisi UndangUndang Nomor 32 Tahun 2004.
Alasan ketiga lebih politis dari pada legalistis, yakni meletakkan keberhasilan atau bahkan kegagalan agenda-agenda dan target-target pembangunan itu sebagai suatu politik citra, yang itu dipandang sebagai keberhasilan atau kegagalan Pemerintah Pusat, Gubernur, atau Bupati-Walikota. Pertanyaan senada juga bisa dilontarkan untuk distribusi dana dekonsetrasi melalui program-program pembangunan yang langsung dilaksakan di tingkat pemerintahan terbawah, figur politik siapakah yang dicitrakan. Dalam konteks kompetensi politik yang tinggi di Indonesia saat ini, citra tampaknya masih memainkan peran yang penting, apalagi bila diingat konstituensi Presiden, Gubernur, Bupati-Walikota, dan partai politik yang berhimpit. Mengelola meeting pot, tapi sekaligus juga kontestasi, kepentingan politik semacam ini merupakan kepelikan tersendiri, karena Gubernur, sebagaimana juga Presiden dan BupatiWalikota adalah agen-agen politik yang juga punya kepentingan politik, sehingga citra, baik positif atau pun negatif selalu sensitif secara politik pula.

Relasi di dalam tata kelola pemerintahan yang baik, yakni melaksanakan desentralisasi secara konsisten, hingga batas Gubernur memainkan porsi peran sebagai wakil pemerintahan pusat atau kepala wilayah administratif untuk dihadapkan sebagai peran kepala daerah otonom. Dalam satu keadaan, relasi ini dapat bersifat saling meniadakan, yakni bilamana porsi peran sebagai Gubernur sebagai wakil pemerintahan pusat atau kepala wilayah administratif membesar, maka porsi peran sebagai kepala daerah otonom dapat menyusut. Ini berarti agenda nasional lebih mendominasi daripada agenda-agenda daerah. Sebaliknya, peningkatan porsi peran Gubernur sebagai kepala daerah otonom menurunkan porsi peran Gubernur sebagai wakil pemerintahan pusat atau kepala wilayah administratif.

Pengaturan yang lebih jauh tentang hal ini sangat dibutuhkan, mengingat sekarang ini Indonesia berada dalam konstelasi rezim desentralisasi yang bagaimanapun menuntut aksentuasi agenda-agenda daerah. Patut dicatat pula bahwa apa yang dimaksud dengan agenda-agenda daerah itu sendiri tidaklah tunggal karena di dalamnya terdapat agenda-agenda kabupaten/kota dan provinsi masing-masing sebagai daerah otonom.

Apa yang dibutuhkan dalam pengaturan itu adalah keseimbangan antara dua peran itu agar 
desentralisasi tetap kentara mewarnai pembangunan Indonesia yang berprinsip negara kesatuan. Ini adalah agenda penting untuk menghilangkan kesan bahwa penguatan Gubernur sebagai wakil pemerintahan pusat atau kepala wilayah administratif adalah proses resentralisasi yang mengutamakan agendaagenda pemerintah pusat dan melemahkan otonomi provinsi dan kabupaten/kota. Penguatan Gubernur secara normatif tetap harus dibaca dalam satu tarikan napas, yakni sebagai penguatan Gubernur wakil pemerintahan pusat atau kepala wilayah administratif dan sekaligus sebagai kepala daerah otonom, termasuk relasi Gubernur secara horizontal dengan Bupati/Walikota yang juga sebagai kepala daerah otonom. Pengaturan ini berisi azas-azas penuntun dan anasir-anasir pokok tentang batasan peran Gubernur sebagai wakil pemerintahan pusat atau kepala wilayah administratif, sebagai kepala daerah otonom, dan dalam relasi horisontalnya dengan kabupaten-kota, serta yang paling penting adalah keseimbangan yang harus dimainkan di antara peran ganda itu.

Berdasarkan hal tersebut di atas, dapat dirangkum sebuah strategi penguatan peran Gubernur yang memuat pergerakan bertahap desentralisasi wewenang kementerian dan lembaga non kementerian ke tangan Gubernur sebagai wakil pemerintah pusat di daerah, termasuk pemetaan kapasitas dan agenda perbaikan kapasitas perangkat serta sistem pendukungnya. Strategi ini dapat dipandang sebagai suatu gerakan "Desentralisasi Generasi Kedua" di mana penguatan hubungan antar pemerintah dan keseimbangan peran Gubernur menjadi agenda pokoknya.

\section{PENUTUP}

\section{Kesimpulan}

Pola hubungan antara Gubernur dengan Bupati/ Walikota dalam kaitannya dengan pelaksanaan tata pemerintahan yang baik adalah bahwa dalam pelaksanaan peran Gubernur sebagai wakil pemerintah pusat, maka hubungan antara Gubernur dengan Bupati/Walikota bersifat bertingkat di mana Gubernur dapat melakukan peran pembinaan dan pengawasan terhadap penyelenggaraan pemerintahan daerah. Sebaliknya Bupati/Walikota dapat melaporkan permasalahan yang terjadi dalam penyelenggaraan pemerintahan di daerah, termasuk dalam hubungan antar kabupaten/kota dengan provinsi. Pola hubungan antar tingkat pemerintahan, khususnya antara provinsi dan kabupaten/kota dianggap penting karena menyangkut efektifitas kinerja pemerintahan dalam melayani masyarakatnya.

\section{Rekomendasi}

Gubernur sebagai wakil pemerintah pusat dan diposisikan sebagai intermediate government maka diperlukan pengaturan lebih jauh agar terjadi penguatan hubungan antar pemerintah guna efektifitas kinerja pemerintahan.

\section{DAFTAR PUSTAKA}

\section{Peraturan Perundang-undangan:}

Undang-Undang Dasar 1945.

Undang-Undang Nomor 22 Tahun 1999 tentang Otonomi Daerah.

Undang-Undang Nomor 28 Tahun 1999 tentang Penyelenggara Negara Yang Bersih dan Bebas Dari Kolusi, Korupsi, dan Nepotisme.

Undang-Undang Nomor 32 Tahun 2004 tentang Pemerintahan Daerah.

Peraturan Pemerintah Nomor 23 Tahun 2011 tentang Perubahan atas Peraturan Pemerintah Nomor 19 Tahun 2010 tentang Tatacara Pelaksanaan Tugas dan Wewenang Serta Kedudukan Keuangan Gubernur Sebagai Wakil Pemerintah di Wilayah Provinsi.

\section{Buku:}

Asshiddiqie, Jimly, 2005, Format Kelembagaan Negara dan Pergeseran Kekuasaan Dalam UUD 1945, Yogyakarta: FH UII Press.

Bovens, M.A.P. (et.all), 1987, Rechts Staaten Sturing, Zwolle: W.E.J. Tjeenk Willing.

Effendi, Lutfi, 2004, Pokok-Pokok Hukum Administrasi, Malang: Bayumedia Publishing.

Halim, Hamzah, 2009, Persekongkolan Rezim Politik Lokal, Study Atas Relasi Antara Eksekutif dan Legislatif, Makassar: Pukap Indonesia.

Huda, Ni'matul, 2007, Pengawasan Pusat Terhadap Daerah dalam penyelenggaraan Pemerintahan Daerah, Yogyakarta: FH UII Press.

Kaloh, J., 2002, Mencari Bentuk Otonomi Daerah, Jakarta: Rineka Cipta.

Lubis, M. Solly, 2002, Hukum Tata Negara, Bandung: Mandar Maju. 
Marbun, S.F. dan Moh. Mahfud, 2000, Pokok-Pokok Hukum Administrasi Negara, Yogyakarta: Liberty.

Marbun, S.F. dkk., 2001, Dimensi-Dimensi Pemikiran Hukum Administrasi Negara, Yogyakarta: UII Press.

Moeliono, Anton dkk., 1989, Kamus Besar Bahasa Indonesia, Jakarta: Balai Pustaka.

Ridwan H.R., 2002, Hukum Administrasi Negara, Yogyakarta: UII Press.

Sedarmayanti, 2004, Good Governance (Kepemerintahan Yang Baik), Bagian Kedua, Bandung: Mandar Maju.
Thoha, Miftah, 2004, Birokrasi dan Politik di Indonesia. Jakarta: Raja Grafindo Persada.

Utrech, E., 1990, Pengantar Hukum Administrasi Negara Indonesia, Jakarta: Ichtiar Baru.

\section{Jurnal:}

Abdullah, Kasman, "Penyelenggaraan Pemerintahan Dalam Konsep Good Governance", Jurnal Meritokrasi, Vol. 1 No. 1, Makassar, 2002.

Hoessein, Bhenyamin, "Kebijakan Desentralisasi", Jurnal Administrasi Negara, Vol. 1 No. 02 Tahun 2002. 